Arch. Environ. Contam. Toxicol. 17, 95-101 (1988)

\title{
Short-Term Lethality and Sediment Avoidance Assays with Endrin-Contaminated Sediment and Two Oligochaetes from Lake Michigan
}

\author{
Timothy J. Keilty ${ }^{\mathrm{x}, 1}$, David S. White ${ }^{\mathrm{x}}$, and Peter F. Landrum ${ }^{+}$ \\ x Great Lakes Research Division, 1061 North University Building, University of Michigan, Ann Arbor, Michigan 48109, and \\ +National Oceanic and Atmospheric Administration, Great Lakes Environmental Research Laboratory, Ann Arbor, Michigan 48104
}

\begin{abstract}
Mean 96-hr $\mathrm{LC}_{50}$ values and standard deviations for the oligochaetes $S$. heringianus and $L$. hoffmeisteri exposed to endrin-contaminated sediment were $2,588 \pm 1,974 \mu \mathrm{g} / \mathrm{g}$ dry weight sediment for 4 assays and $2,725 \pm 955 \mu \mathrm{g} / \mathrm{g}$ for 2 assays, respectively. Mixed species testing data suggested that the toxicity to L. hoffmeisteri was reduced in the presence of $S$. heringianus, yet further testing is required. Ninety-six hour $\mathrm{EC}_{50}$ burrowing avoidance values for both species ( 19 and $15.3 \mu \mathrm{g} / \mathrm{g}$ for $S$. heringianus and $59 \mu \mathrm{g} / \mathrm{g}$ for $L$. hoffmeisteri) were approximately 46 and 150 times lower than their respective mean $96-\mathrm{hr} \mathrm{LC}_{50}$ values. Both $S$. heringianus and $L$. hoffmeisteri initially burrowed in contaminated sediment and then returned to the surface in numbers somewhat proportional to the sediment concentration and the length of exposure. Future use of oligochaete behavioral responses to sublethal sediment contamination for pollutant impact on benthic communities is promising.
\end{abstract}

Toxic compounds with high partition coefficients that enter the Laurentian Great Lakes adsorb significantly to fine particles and settle to the bottom. The fate of these compounds and their interactions with the larger benthic organisms is largely unknown. Compound fates normally depend on complex combinations of sediment and xenobiotic chemical/physical properties and the activity pat-

\footnotetext{
${ }^{1}$ To whom correspondence should be addressed (Univ. of Mich.)
}

terns of the larger benthos (Petr 1977), Oligochaetes are of particular interest because they are frequently the dominant macrobenthic taxa, and because they rework (mix) sediments in a conveyorbelt fashion (Davis 1974; Krezoski et al. 1978; Robbins et al. 1979; McCall and Fisher 1980; Robbins 1982; Krezoski and Robbins 1985; Robbins 1986), which can result in profound alterations of sediment characteristics (Robbins 1982; Fisher 1982; McCall and Tevesz 1982). Despite the importance of the oligochaetes, very few studies have examined contaminated sediment-oligochaete interactions.

In previous freshwater oligochaete studies, contaminants were usually placed in solution, either without a sediment substrate or in the presence of uncontaminated sediment. The responses of several freshwater oligochaete species under these conditions have been determined for cadmium, mercury, pentachlorophenol, pulp mill effluent, and sewage sludge in water, and in water and uncontaminated sediment under a range of dissolved oxygen and temperatures (Chapman et al. 1982a, $1982 \mathrm{~b}, 1982 \mathrm{c})$. Death and changes in respiration were used as the measures of response. In most experiments, 96-hr $\mathrm{LC}_{50}$ values increased (toxicity was decreased) when uncontaminated sediments were added. Survival was also enhanced and a decrease in community respiration was observed when Limnodrilus hoffmeisteri (Tubificidae) and Tubifex tubifex (Tubificidae) were exposed together to the above pollutants without sediment (Chapman et al. 1982a). Additionally, the toxicities of twentythree insecticides to Branchiura sowerbyi (Tubificidae) were generally reduced when uncontaminated sediment was added to test solutions (Naqvi 
1973), as were the toxicities of heavy metals and nitroaromatic compounds to Lumbriculus variegatus (Lumbriculidae) (Bailey and Lui 1980). Oligochaetes were exposed directly to contaminated sediments in only one study (Karickhoff and Morris 1985). The intent of their study, however, was to examine the role of tubificids in toxicant transport, and not to determine lethal and sublethal responses by the organisms.

By virtue of their persistence and relative toxicity, compounds with high partition coefficients that sorb to the fine grained, organic fraction of the sediments pose serious potential health hazards to man. Although benthic organisms are an integral part of the aquatic food web, lethal testing of oligochaetes in contaminated sediments has not been reported. Contaminated sediments should afford a more natural testing medium than water (Chapman et al. 1982b) and provide an optimal medium for exposures to hydrophobic toxicants. Use of contaminated sediments also allows potential sublethal responses to be examined and quantified, such as changes in burrowing behavior at exposure levels approaching levels that have been found in the environment.

The objective of this research was to compare the lethal and behavioral responses, including an ancillary examination of mixed species effects in lethality tests, to a sediment bound toxicant by two freshwater oligochaetes: Stylodrilus heringianus (Lumbriculidae) and Limnodrilus hoffmeisteri (Tubificidae).

\section{Materials and Methods}

The chlorinated pesticide endrin $(1,2,3,4,10,10$, hexachloro-6,7epoxy-1,4,4a,5,6,7,8,8a-octahydro-1,4-endo,endo-5,8-dimethanonaphthalene) was chosen because of its sorption characteristics $\left(\log \mathrm{k}_{\mathrm{ow}}=5.6\right.$, Neely et al. 1974$)$, its toxicity to other aquatic species (Grant 1976), and its availability in a commercially radiolabeled form (Pathfinder Laboratories, Inc, St. Louis, MO). Although concentrations in the sediments of the Great Lakes today are negligible (Frank et al. 1981a, 1981b), endrin represents one of hundreds of highly-sorbed, potentially toxic compounds.

Lake Michigan sediments were collected in October, 1983, with a Ponar grab approximately $10 \mathrm{~km}$ offshore from St. Joseph, Michigan, at a water depth of $42 \mathrm{~m}$. To create a uniform sediment for experiments, sediments were dried at $60^{\circ} \mathrm{C}$, passed through a $0.25 \mathrm{~mm}$ mesh sieve, and thoroughly mixed. Sediments were reconstituted as needed with lake water and a few $\mathrm{ml}$ of fresh sediment to provide an active bacterial flora.

Worms were collected at the sediment collection site in March or April of 1984, 1985, and 1986 and maintained in the dark at $10^{\circ} \mathrm{C}$ in $200 \mathrm{~L}$ aquariums for a minimum of 1 month prior to use. Aquarium sediments were gently sieved $(0.5 \mathrm{~mm}$ mesh) to con- centrate worms. A fiber-optic light (to prevent unnecessary heating) and a dissecting microscope were used to sort and identify worms.

For each experimental concentration, endrin: ${ }^{14} \mathrm{C}$-endrin (1000:1) was added to reconstituted sediments via $<1 \mathrm{ml}$ acetone carrier $(<1 \mathrm{ml}$ acetone carrier also added to controls), and the mixture was stirred for $24 \mathrm{hr}$ in $2 \mathrm{~L}$ Lake Michigan water. After settling $72 \mathrm{hr}$, overlying water, containing the acetone, was aspirated off and enough fresh aerated lake water was added back to the sediments (and restirred for approx. $10 \mathrm{~min}$ ) to allow the resulting slurry to be poured equally into $50 \mathrm{ml}$ Griffen beakers. The slurries were allowed to settle for $72 \mathrm{hr}$ at $10^{\circ} \mathrm{C}$. Each beaker received approximately $25 \mathrm{~g}$ dry weight sediment and $25 \mathrm{ml}$ water. Five to fifteen worms/beaker were added at this time. All experimental concentrations and controls were run in triplicate except where noted.

Four 96-hr lethal and two 96-hr sediment avoidance assays were completed between October 1984 and August 1986. Two of the 96-hr lethal assays included both single and mixed species testing. Death was defined as absence of color and response to touch, and an unmistakable degree of body degeneration. Observations of burrowing behavior were made at $0.17,0.5,2,8$, $16,24,48$, and $96 \mathrm{hr}$ during one $\mathrm{EC}_{50}$ assay for time series analysis. A worm was considered unburrowed if greater than an estimated $75 \%$ of its body was exposed on the sediment surface.

In single species lethality tests (assays 1-4), 10 worms/beaker (30 total/concentration) were used. Five worms/species/beaker were used in one mixed species $\mathrm{LC}_{50}$ assay and 10 worms/ species/beaker in a follow-up assay (run simultaneously with single species assays 3 and 4, respectively) to better define a potential mixed species response. Fifteen worms/beaker (45 worms total/concentration) were used in the first sediment avoidance $\mathrm{EC}_{50}$ assay, and 10 worms/beaker $(20$ worms total/ concentration) were used in the second assay. Fewer worms/ beaker were used in the second avoidance assay to facilitate counting. Worms for the second sediment avoidance assay were added individually, and spaced out over the sediment surface. In all other assays, worms were temporarily placed in $20 \mathrm{ml}$ vials of aerated lake water until sufficient numbers were obtained to begin an experiment. Typically, the worms formed a 'ball' which was gently added to each beaker. At higher concentrations, even though some worms burrowed and then emerged from the sediments, worms on the surface remained loosely entangled making exact counts difficult. The protocol of 10 worms/beaker in the second $\mathrm{EC}_{50}$ assay eliminated this difficulty. Twenty worms (duplicate instead of triplicate replication) were used in the second assay.

All experiments were conducted in an environmental chamber maintained at $10^{\circ} \mathrm{C}$ in the dark. Darkness was maintained to eliminate light-stimulated burrowing responses (White unpublished data). Overlying water in each beaker was not replaced during experiments. In sediment avoidance experiments, counts of worms on the sediment surface were made under a dissecting microscope when necessary, and beakers immediately returned to the chamber.

Post experimental sediment endrin: ${ }^{14} \mathrm{C}$-endrin concentrations were determined by liquid scintillation, using a Packard $460 \mathrm{C}$ counter. Endrin was removed from the sediment by 8 -hr Soxhlet extraction in $240 \mathrm{ml}$ hexane and $60 \mathrm{ml}$ acetone (Sharom et al. 1980). Extraction volumes were reduced with a Buchler flash evaporator to approximately $1 \mathrm{ml}$ to concentrate samples. Liquid scintillation determinations were initially verified by gas chromatography (Varian Aerograph Series 1200, column temp. 
Table 1. Measured sediment endrin concentrations in $\mu \mathrm{g} / \mathrm{g}$ dry weight sediment for four $96-\mathrm{hr} \mathrm{LC}_{50}$ assays and two 96 -hr sediment avoidance $\mathrm{EC}_{50}$ assays

\begin{tabular}{ll}
\hline $96-\mathrm{hr} \mathrm{LC}_{50}$ assay & Sediment Concentrations \\
\hline 1 & $0,72,251,298,512,829,1092$ \\
2 & $0,121,279,421,982$ \\
3 & $0,4.4,91,432,1352$ \\
4 & $98,414,801,1848$ \\
\hline $96-\mathrm{hr} \mathrm{EC}_{50}$ assay & Sediment Concentrations \\
\hline 1,2 & $0,1.2,10.7,23.9,52.4,77.2,104.1$ \\
\hline
\end{tabular}

$210^{\circ} \mathrm{C}$, detector temp. $230^{\circ} \mathrm{C}$ ). Clean-up of samples for gas chromatographic analyses was with Florisil ${ }^{\mathbb{B}}$ and followed the procedure in the Pesticide Analytical Manual (1977). Prior to use, the radiopurity of the labeled endrin was determined by thin layer chromatography (Patil et al. 1970) and was found to be $>98 \%$.

$\mathrm{EC}_{50}$ and $\mathrm{LC}_{50}$ data with upper and lower $95 \%$ confidence limits were generated, using the Litchfield and Wilcoxon (1949) $\log$ probit nomographic method.

\section{Results}

Measured sediment concentrations in $96-\mathrm{hr} \mathrm{LC}_{50}$ assays $1-4$ ranged from a low of $4.4 \mu \mathrm{g} / \mathrm{g}$ in assay 3 to a high of $1,848 \mu \mathrm{g} / \mathrm{g}$ in assay 4 (Table 1 ). The same sediments were used in both $96 \mathrm{hr} \mathrm{EC}_{50}$ assays and measured endrin concentrations ranged from 1.2 to $104 \mu \mathrm{g} / \mathrm{g}$ (Table 1 ).

No mortality occurred in any of the control beakers, and all control worms burrowed and remained in the sediment in all assays.

Ninety-six hour $\mathrm{LC}_{50}$ data with iower and upper 95\% confidence limits for $S$. heringianus and $L$. hoffmeisteri were reasonably similar (Table 2). The mean $\mathrm{LC}_{50}$ and standard deviation for single species testing with $S$. heringianus was $2,588 \pm$ $1,974 \mu \mathrm{g} / \mathrm{g}(\mathrm{n}=4)$. Most of the variance occurred as a result of the high $(5,400 \mu \mathrm{g} / \mathrm{g})$ value obtained in assay 4 . The mean $\mathrm{LC}_{50}$ for $L$. hoffmeisteri was comparable $(2,725 \pm 955, \mathrm{n}=2)$. In mixed species testing (assay 3, Table 2), the $\mathrm{LC}_{50}$ for $S$. heringianus $(2,750 \mu \mathrm{g} / \mathrm{g})$ was not significantly different from the mean single species value $(2,588 \mu \mathrm{g} / \mathrm{g})$. A significant increase in tolerance (as measured by Litchfield-Wilcoxon slope comparison method, $\mathrm{p}<$ 0.05 ) was apparent for $L$. hoffmeisteri in the mixed species assay $(5,600 \mu \mathrm{g} / \mathrm{g}$ vs $2,725 \mu \mathrm{g} / \mathrm{g})$. However, in the mixed species aspect of assay 4 , no dose response relationship was observed; thus, assay 4 could not be compared with assay 3 .

Ninety-six hour $\mathrm{EC}_{50}$ assays for $S$. heringianus yielded values of 19 and $15.3 \mu \mathrm{g} / \mathrm{g}$, compared with a
Table 2. Ninety-six hour $\mathrm{LC}_{50}$ values ( $\mu \mathrm{g} / \mathrm{g}$ endrin dry wt. sediment) with upper and lower $95 \%$ confidence limits for Stylodrilus heringianus and Limnodrilus hoffmeisteri in single and mixed tests

\begin{tabular}{llcr}
\hline & & \multicolumn{2}{c}{$95 \%$ Confidence Limits } \\
\cline { 4 - 4 } Species & $\mathrm{LC}_{50}(\mu \mathrm{g} / \mathrm{g})$ & Upper & Lower \\
\hline S. heringianus & & & \\
Assay 1 & 1400 & 1442 & 1359 \\
Assay 2 & 1050 & 1095 & 1007 \\
Assay 3 & 2500 & 5416 & 1157 \\
Assay 4 & 5400 & 10487 & 2781 \\
L. hoffmeisteri & & & \\
Assay 3 & 2050 & 4045 & 1041 \\
Assay 4 & 3400 & 5076 & 2277 \\
Mixed Species & & & \\
Assay 3 & & & \\
S. heringianus & 2750 & 7838 & 965 \\
L. hoffmeisteri & 5600 & 13104 & 2393 \\
Combined response & 4000 & 10720 & 1.493 \\
Assay 4 & $a$ & & \\
\hline
\end{tabular}

a no dose response

value of $59 \mu \mathrm{g} / \mathrm{g}$ for $L$. hoffmeisteri (Table 3). L. hoffmeisteri was not used in assay 1 , because at the time it was not in the protocol.

$\mathrm{EC}_{50}$ data generated over different time frames demonstrated that both species initially burrowed into highly contaminated sediment and then returned to the surface. At $0.5 \mathrm{hr}$, the $\mathrm{EC}_{50}$ for $S$. heringianus was $1,000 \mu \mathrm{g} / \mathrm{g}$ and $300 \mu \mathrm{g} / \mathrm{g}$ for $L$. hoffmeisteri (Table 4). After $2 \mathrm{hr}, \mathrm{EC}_{50}$ values dropped to $180 \mu \mathrm{g} / \mathrm{g}$ and $255 \mu \mathrm{g} / \mathrm{g}$, respectively. Each species reached an approximate equilibrium in response $(8$ $\mathrm{hr}$ for $S$. heringianus and 32 to $48 \mathrm{hr}$ for L. hoffmeisteri) well before the 96 hr termination (Figures 1 and 2).

\section{Discussion}

\section{Lethal Responses}

Endrin is extremely toxic to aquatic organisms, producing $96-\mathrm{hr} \mathrm{LC}_{50}$ values of $1 \mu \mathrm{g} / \mathrm{L}$ or less for bluegills, trout, salmon, fathead minnows (Grant 1976) and flagfish (Hermanutz et al. 1985). It is slightly less toxic to freshwater Crustacea with reported $\mathrm{LC}_{50}$ values of 1.3 to $3 \mu \mathrm{g} / \mathrm{L}$ for two species of Gammaris and $320 \mu \mathrm{g} / \mathrm{L}$ for mature crayfish (Sanders 1972). Although the literature is sparse, the oligochaetes are more resistant to endrin (Naqvi 1973) as well as to DDT, Sevin, malathion, and methoxychlor (Bailey and Lui 1980). However, 
Table 3. Ninety-six hour burrowing avoidance $\mathrm{EC}_{50}$ values $(\mu \mathrm{g} / \mathrm{g}$ endrin dry weight sediment) with upper and lower $95 \%$ confidence limits for Stylodrilus heringianus and Limnodrilus hoffmeisteri

\begin{tabular}{llll}
\hline & & \multicolumn{2}{l}{$95 \%$ Confidence Limits } \\
\cline { 3 - 4 } Species & $\mathrm{EC}_{50}(\mu \mathrm{g} / \mathrm{g})$ & Upper & Lower \\
\hline $\begin{array}{l}\text { S. heringianus } \\
\text { Assay 1 }\end{array}$ & 19.0 & 22.4 & 16.1 \\
Assay 2 & 15.3 & 21.1 & 11.1 \\
L. hoffmeisteri & $\mathrm{a}$ & & \\
Assay 1 & 59 & 38 & 92 \\
Assay 2 & & & \\
\hline
\end{tabular}

a not used in assay 1

Table 4. Burrowing avoidance $\mathrm{EC}_{50}$ values $(\mu \mathrm{g} / \mathrm{g}$ endrin dry weight sediment) with upper and lower $95 \%$ confidence limits for Stylodrilus heringianus and Limnodrilus hoffmeisteri at selected time intervals

\begin{tabular}{|c|c|c|c|c|c|c|}
\hline \multirow[b]{3}{*}{ Time (hr) } & \multicolumn{6}{|c|}{ Species } \\
\hline & \multicolumn{3}{|c|}{$\begin{array}{l}\text { S. heringianus } \\
95 \% \text { C.L. }\end{array}$} & \multicolumn{3}{|c|}{$\begin{array}{l}\text { L. hoffmeisteri } \\
\text { 95\% C.L. }\end{array}$} \\
\hline & $\mathrm{EC}_{50}$ & Upper & Lower & $\mathrm{EC}_{50}$ & Upper & Lower \\
\hline 0.17 & 95 & 210 & 43 & 300 & 628 & 143 \\
\hline 0.5 & 1000 & 4410 & 227 & 300 & 628 & 143 \\
\hline 2 & 180 & 349 & 93 & 255 & 504 & 129 \\
\hline 8 & 17.5 & 30.7 & 9.9 & 118 & 172 & 81 \\
\hline 16 & 16.0 & 23.1 & 11.0 & a & & \\
\hline 24 & 15.3 & 21.1 & 11.1 & 90 & 129 & 63 \\
\hline 32 & a & & & 66 & 101 & 43 \\
\hline 48 & 15.3 & 21.1 & 11.1 & 59 & 92 & 38 \\
\hline 96 & 15.3 & 21.1 & 11.1 & 59 & 92 & 38 \\
\hline
\end{tabular}

a no observation made

all previous acute oligochaete testing has involved aqueous test solutions.

In pesticide studies involving oligochaetes (Whitten and Goodnight 1966, Naqvi 1973), toxicities of test solutions were significantly reduced when sediment was added (Naqvi 1973). The ability of sediments to modify toxicity was also demonstrated with chlorinated pesticides and fish (Ferguson et al. 1965), kepone and chironomid larvae (Adams et al. 1985), and a hexachlorobiphenyl isomer and amphipods (Lynch and Johnson 1982). The modifying effect(s) of the sediment in these studies was attributed to a reduction in the bioavailability of the toxicants due to sorption, particularly with the most hydrophobic compounds. Addition of sediment also resulted in higher survival rates of twelve oligochaetes exposed to pentachlorophenol, black liquor, mercury, cadmium, and sewage (Chapman et al. 1982b). The ability to better cope

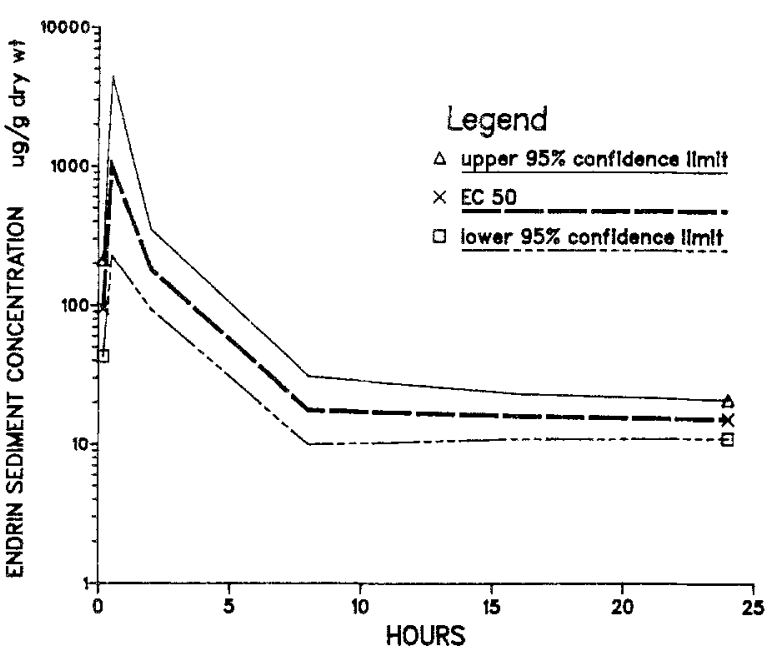

Fig. 1. Sediment avoidance $\mathrm{EC}_{50}$ data with upper and lower $95 \%$ confidence limits for Stylodrilus heringianus. Forty-eight and ninety-six hour values are equal to the twenty-four hour value and are not plotted.

with stress under the more natural conditions afforded by the sediment as well as a reduction in toxicant availability were considered responsible for many one-order of magnitude increases in observed $\mathrm{LC}_{50}$ values. The less stressful conditions associated with the use of sediments was illustrated by worms exhibiting heightened tolerances to higher water temperatures in the presence of sediment (Chapman et al. 1982b).

The present exposures using sediment bound endrin resulted in very high $96-\mathrm{hr} \mathrm{LC}_{50}$ values for both oligochaete species (Table 2) when compared to the $\mathrm{LC}_{50}$ values for other aquatic species tested in aqueous endrin solutions. In all likelihood, the high sorptive properties and concurrent reduction in availability of the toxicant are primarily responsible for the low toxicity, and the presence of the sediment acting as a more natural medium secondary. Regardless, the data suggest that oligochaetes may be able to withstand substantial amounts of highly toxic, sorbed pollutants.

Species interactions among tubificids increase the tolerance to some pollutants in aqueous test solutions (Chapman et al. 1982a). We desired to see if a similar relationship existed between a lumbriculid and a tubificid exposed to contaminated sediment. Although it appeared from the mixed species testing in assay 3 that the toxicity to L. hoffmeisteri was reduced (Table 2 ), when repeated using twice the number of individuals ( 10 worms/species/ beaker) in assay 4 , no dose response was observed. Although tolerance changes due to species interactions are suggested, further work is clearly necessary. 


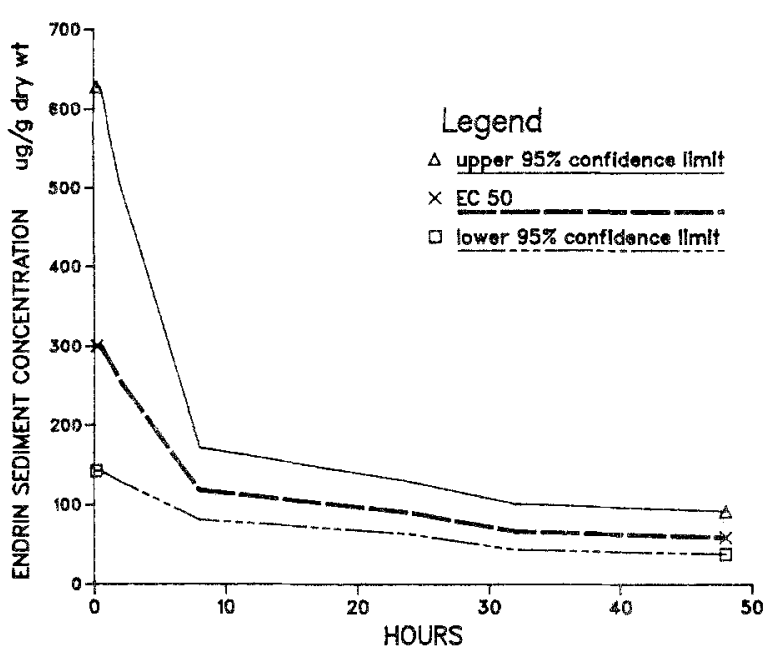

Fig. 2. Sediment avoidance $\mathrm{EC}_{50}$ data with upper and lower $95 \%$ confidence limits for Limnodrilus hoffmeisteri. The ninety-six hour value equals the forty-eight hour value and is not plotted.

\section{Sublethal Responses}

Sublethal impairment of an animal's development or its capacity to live and compete in its environment reduces the chances of survival for both the individual, and in extreme cases, the entire species (Anderson and d'Apollonia 1982).

While conducting the lethal assays, it was noted that, at concentrations one to two orders of magnitude below the $\mathrm{LC}_{50}$, $S$. heringianus did not burrow. Since this observation had not been previously quantified for freshwater oligochaetes in contaminated sediments, $\mathrm{EC}_{50}$ assays were performed, using burrowing as a response. Because sublethal testing often involves exposure far closer to levels sometimes encountered in the environment, low level behavioral response assays may be a more realistic assessment of pollutant impact. The problem with this type of testing is the identification and subsequent quantification of the sublethal response. For oligochaetes, burrowing is an excellent response variable. Additionally, observations of burrowing behavior allow collection of nondestructive time series data, and the ease of conducting an experiment is equal to that of a lethal assay, making its potential promising for assessing pollutant impact on benthic communities.

Although very little is known about freshwater oligochaete behavioral responses to pesticide or other toxicant contaminated sediment, sufficient sediment and/or water concentrations of toxic compounds have been shown to influence burrowing behavior of three species of marine polychaetes. Nereis virens emerged from sediment contaminated with endosulfan, chlordane, dieldrin, DDT, and en- drin (McLeese et al. 1982). Sediments contaminated with parathion, methyl parathion, and malathion caused impaired and almost complete cessa. tion of burrowing by Nereis versicolor (Mohlenberg and Kiorboe 1983). Significant inhibition of both the rate and magnitude of lugworm feeding activity was observed for Arenicola marina in kepone contaminated sea water (Rubinstein 1979).

In the present study, mean $96-\mathrm{hr} \mathrm{EC}_{50}$ values for $L$. hoffmeisteri and $S$. heringianus are approximately 46 and 150 times lower than their respective mean 96-hr $\mathrm{LC}_{50}$ values (Tables 2 and 3). This level of response suggests that sorbed pollutants have the potential to alter benthic communities without directly or immediately killing individuals. Along with other factors, changes in species composition in some instances may be the result of inefficiencies in life-sustaining functions induced in less tolerant species by longterm, low level exposures to dozens, perhaps hundreds, of toxicants residing in lake bottom sediments. Relative to $S$. heringianus, the higher $\mathrm{EC}_{50}$ value observed for $L$. hoffmeisteri may relate to this, as $L$. hoffmeisteri is a eutrophic to mesotrophic species. Even at endrin concentrations of $1,800 \mu \mathrm{g} / \mathrm{g}$ in lethal assays, one to three (of ten) worms consistently would burrow, whereas in concentrations of $50-75 \mu \mathrm{g} / \mathrm{g}$ burrowing behavior ceased altogether for the characteristically more oligotrophic $S$. heringianus. This is in contrast to findings of Chapman et al. (1982b) where in $\mathrm{LC}_{50}$ assays oligotrophic species were often most tolerant to specific chemical pollutants (eutrophic species were more tolerant to sewage sludge and anoxia). One would not anticipate Chapman's result with oligotrophic species based on oligochaete field distribution patterns. In our study, $L_{50}$ values for $S$. heringianus and L. hoffmeisteri were not significantly different, also a result not anticipated in light of field distributions. The observed behavioral responses were, however, consistent with the respective trophic status of each species, implying such tests may be more sensitive indicators of environmental impact of chemical pollutants.

The sensitivity of the behavioral response is further demonstrated in the time series analyses of burrowing behavior $S$. heringianus emerged and remained on the surface after only 8 hr (Figure 1), while $L$. hoffmeisteri returned to the surface after 32 to $48 \mathrm{hr}$ (Figure 2). The faster response of $S$. heringianus (4 times faster than $L$. hoffmeisteri) in returning to the sediment surface may again reflect the anticipated sensitivity associated with the oligotrophic species. The underlying mechanism(s) for this is unknown. The respective abilities to reg- 
ulate respiration may be a factor as $L$. hoffmeisteri is considered a regulator and $S$. heringianus a partial regulator; however, oligochaete respiratory responses to sublethal stress are variable, and changes in $\mathrm{LC}_{50}$ values do not correlate with changes in respiration (reviewed in Chapman and Brinkhurst 1984). In the present study, both $S$. heringianus and $L$. hoffmeisteri would burrow into contaminated sediment and then return to the surface in numbers somewhat proportional to the sediment concentration and the length of exposure. Future use of oligochaete behavioral responses to sublethal sediment contamination for assessment of pollutant impact on benthic communities is promising.

Acknowledgments. The authors gratefully acknowledge John Robbins, Brian Eadie, Wayne Gardener, William Benninghoff, and Eugene Stoermer for critical review of the manuscript. Funding for this study was provided in part by a grant from the Great Lakes Environmental Research Laboratory under the National Oceanic and Atmospheric Administration's Cooperative Agreement NA81-RA-H-00003. Contribution No. 464 from Great Lakes Research Division and No. 551 from Great Lakes Environmental Research Laboratory.

\section{References}

Adams WJ, Kimerle RA, Mosher RG (1985) Aquatic safety assessment of chemicals sorbed to sediments. In: Cardwell RD, Purdy R, Bahner RC (eds) Aquatic Toxicology and Hazard Assessment: Seventh Symposium, ASTM STP 854, American Society for Testing and Materials, Philadelphia, pp 429-453

Anderson PO, d'Apollonia S (1982) Aquatic Animals. In: Butler GC (ed) Principles of Ecotoxicology. J Wiley and Son, New York, pp 187-221

Bailey HC, Lui DHW (1980) Lumbriculus variegatus, a benthic oligochaete, as a bioassay organism. In: Eaton JC, Parrish PR, Hendricks AC (eds) Aquatic Toxicology, ASTM STP 707, American Society for Testing and Materials, Philadelphia, pp 205-215

Chapman PM, Farrell MA, Brinkhurst RO (1982a) Effects of species interactions on the survival and respiration of Limnodrilus hoffmeisteri and Tubifex tubifex (Oligochaeta, Tubificidae) exposed to various pollutants and environmental factors. Water Res 16:1405-1408

(1982b) Relative tolerances of selected aquatic oligochaetes to individual pollutants and environmental factors. Aquatic Toxicol 2:47-67

(1982c) Relative tolerance of selected aquatic oligochaetes to combinations of pollutants and environmental factors. Aquatic Toxicol 2:69-78

Chapman PM, Brinkhurst RO (1984) Lethal and sublethal tolerances of aquatic oligochaetes with reference to their use as a biotic index of pollution. Hydrobiologia 115:139-144

Davis RB (1974) Stratigraphic effects of tubificids in profundal lake sediments. Limnol Oceanogr 19:466-488

Ferguson DE, Ludge JL, Wood JP, Prather JW (1965) The effect of mud on the bioactivity of pesticides on fish. I Miss Acad Sci 11:219-228

Fisher JB (1982) Effects of macrobenthos on the chemical diagnesis of freshwater sediments. In: McCall PL, Tevesz MJS (eds) Animal-Sediment Relations, The Biogenic Alteration of Sediments. Plenum, New York, pp 177-218

Frank R, Thomas RL, Braun HE, Gross DL, Davies TT (1981a) Organochlorine insecticides and PCB in surficial sediments of Lake Michigan (1975). J Great Lakes Res 7:42-50

Frank R, Thomas RL, Holdrenet H, McMillan RK, Braun HE, Dawson R (1981b) Organochlorine residues in suspended solids collected from the mouths of Canadian streams flowing into the Great Lakes 1974-1977. J Great Lakes Res $7: 440-454$

Grant BF (1976) Endrin toxicity and distribution in freshwater: A review. Bull Environ Contam Toxicol 15:283-289

Hermanutz RO, Eaton JG, Mueller LH (1985) Toxicity of endrin and malathion mixtures to flagfish (Jordanella floridae). Arch Environ Contam Toxicol 14:307-314

Karickhoff SW, Morris KR (1985) Impact of tubificid oligochaetes on pollutant transport in bottom sediments. Environ Sci Technol 19:51-56

Krezoski JR, Mozley SC, Robbins JA (1978) Influence of benthic macroinvertebrates on mixing profundal sediments in southeastern Lake Huron. Limnol Oceanogr 23:10111016

Krezoski JR, Robbins JA (1985) The vertical distribution of feeding and particle selective transport of ${ }^{137} \mathrm{Cs}$ in lake sediments in lumbriculid oligochaetes. J Geophys Res 90:11999-12006

Litchfield JV, Wilcoxon F (1949) A simplified method for evaluating dose effect experiments. J Pharmac Exp Ther 96:49113

Lynch TR, Johnson HE (1982) Availability of a hexachlorobiphenyl isomer to benthic amphipods from experimentally contaminated natural sediments. In: Pearson JG, Foster RB, Bishop WE (eds) Aquatic Toxicology and Hazard Assessment: Fifth Conference, ASTM STP 766, American Society for Testing and Materials, Philadelphia, pp 273-287

McCall PL, Fisher JB (1980) Effects of tubificid oligochaetes on physical and chemical properties of Lake Erie sediments. In: Brinkhurst RO, Cook DG (eds) Aquatic Oligochaete Biology, Plenum, New York, pp 253-318

McCall PL, Tevesz MJS (1982) The effects of benthos on physical properties of freshwater sediments. In: McCall PL, Tevesz MJS (eds) Animal-Sediment Relations, The Biogenic Alteration of Sediments. Plenum, New York, pp 105-176

McLeese DW, Burridge LE, Van Dinter J (1982) Toxicities of five organochlorine compounds in water and sediment to Nereis virens. Bull Environ Contam Toxicol 28:21-220

Mohlenberg F, Kiorboe T (1983) Burrowing and avoidance behavior in marine organisms exposed to pesticide-contaminated sediment. Mar Pollut Bull 14:57-60

Naqvi SMZ (1973) Toxicities of twenty-three insecticides to a tubificid worm Branchiura sowerbyi from the Mississippi delta. J Econ Entomol 66:70-74

Neely WB, Branson DR, Blau GE (1974) Partition coefficient to measure bioconcentration potential of organic chemicals in fish. Environ Sci Technol 8:1113-1115

Patil KC, Matsumura F, Boush GM (1970) Degradation of endrin, aldrin, and DDT by soil microorganisms. Appl Microbiol 19:879-881

Pesticide Analytical Manual (1977) US Dept Health, Education 
and Welfare. Food and Drug Administration, Washington, DC

Petr $T$ (1977) Bioturbation and exchange of chemicals in the mud-water interface. In: Golterman HL (ed) Interactions between sediments and freshwater. Junk Publ., The Hague, pp 216-225

Robbins JA, McCall PL, Fisher JB, Krezoski JR (1979) Effect of deposit feeders on migration of cesium-137 in lake sediments. Earth Planet Sci Lett 42:277-287

Robbins JA (1982) Stratigraphic and dynamic effects of sediment reworking by Great Lakes zoobenthos. Hydrobiologia 92:611-622

(1986) A model for particle-selective transport of tracers in sediments with conveyor-belt deposit feeders. J Geophys Res 91:8542-8558

Rubinstein NI (1979) A benthic bioassay using time-lapse photography to measure the effect of toxicants on the feeding behavior of lugworms (Polychaeta:Arenicolidae). In: Vern berg WB, Calabrese A, Thurberg FP, Vernburg FJ (eds) Marine Pollution: Functional Responses. Academic Press, New York, pp 341-351

Sanders HO (1972) Toxicity of some insecticides to four species of malocostracan crustaceans. Bur Sport Fish Wild Tech Paper No 66, pp 19

Sharom MS, Miles JRW, Harris CR, McEwen FL (1980) Behavior of 12 insecticides in soil and aqueous suspensions of soil and sediment. Water Res 14:1095-1100

Whitten BK, Goodnight CJ (1966) Toxicity of some common insecticides to tubificids. I Water Pollut Control Fed 38:227235

Manuscript received January 30,1987 and in revised form April 15, 1987. 